\title{
PERANCANGAN SISTEM INFORMASI KEPEGAWAIAN BERBASIS WEBSITE DI BAGIAN KEPAGAWAIAN SDN BINAKARYA I KABUPATEN GARUT
}

\author{
Mohamad Reza Fachlevi \\ Fakultas Teknik dan Ilmu Komputer, Program Studi Sistem Informasi \\ Universitas Komputer Indonesia \\ Email: reizza@hotmail.co.uk \\ R. Fenny Syafariani \\ Fakultas Teknik dan Ilmu Komputer, Program Studi Sistem Informasi \\ Universitas Komputer Indonesia \\ Email: r.fenny.syafariani@email.unikom.ac.id
}

\begin{abstract}
ABSTRAK
Sistem informasi kepegawaian merupakan sebuah sistem yang bertujuan untuk mengelola data kepegawaian sebuah, kebutuhan akan informasi pada saat ini semakin meningkat hal ini memnuntut kinerja sebuah informasi untuk cepat dan dapat di dapat di percaya dalam mengelola informasi. Namun dalam hal ini pelaksanaan Sistem informasi kepegawaian di SDN BINAKARYA 1 masih mengalami beberapa kendala, seperti dalam hal pengolahan data KGB, Kenaikan pangkat, kepensiunan serta penilaian pegawai. Oleh sebab itu, maka dikembangkanlah sistem informasi kepegawaian tersebut dengan tujuan untuk membantu proses pengajuan pensiun, KGB, kenaikan pangkat, penilaian pegawai sehingga dapat mempercepat pekerjaan.Dalam penelitian ini metode penelitian yang digunakan ialah metode deskriptif dan tindakan (aksi) serta untuk merancang sistem informasi kepegawaian digunakan pendekatan berorientasi objek (OOP) dan untuk metode pengembangan menggunakan metode prototipe, serta alat bantu yang digunakan adalah usecase, activity diagram, class diagram, object diagram dan deployment diagram.Hasil dari penelitian ini adalah sebuah sistem informasi kepegawaian yang dapat membantu pegawai dalam menyipkan persyaratan kenaikan pangkat kepensiunan penilaian pegawai dengan adanya sebuah database yang terintegrasi.
\end{abstract}

Kata kunci: sistem informasi kepegawaian, pendekatan berorientasi objek (OOP), prototipe, deskriptif.

\section{ABSTRACT}

Personnel information system is a system for manage employe personnel data that need for information on the currently period is increasing this demending performance information for a fast and can be trusted to manage the information. But in this case the implementation of Personnel information systems at SDN BINAKARYA 1 still experienced some constraint, such as in the case of data processing $n$ terms of processing data of the KGB, promotion, retirement as well as an assessment of employees. Therefore, then developed the Personnel information system with the purpose to assist the process of submission retires, the $K G B$, promotion, assessment officers so as to facilitate the work.In this research the research method used in this tesis is descriptive method and act(action) as well as to design staffing information system using object-oriented approach (OOP) and for the development of a method using the method prototype, as well as the tools used is a usecase, activity diagrams, class diagrams, object diagrams and deployment diagramsThe results of this research is an personnel information systems who are help the Administration in the exercise of his duties.

Keywords: personnel information system, object-oriented (OOP), descriptive method, prototype.

\section{PENDAHULUAN}

Teknologi informasi sekarang ini sudah mengakar kepada seluruh sektor kehidupan manusia dengan adanya perkembangan komputer yang sangat pesat membuat pengolahan informasi menjadi cepat dan lebih efisien. Teknologi informasi terdiri dari teknologi komputer (hardware serta software) membatu dalam meproses dan mengelola informasi [1] atau dapat di artikan teknologi informasi menyatukan komputasi dan komunikasi berkecapatan tinggi untuk data, suara, dan video demi menunjang kebutuhan manusia [2] 
Sistem merupakan sebuah kumpulan prosedur yang saling berhubungan dan melakukan pekerjaan bersama-sama untuk mencapai tujuan bersama.[3]. Informasi adalah data mentah yang telah di olah sedemikian rupa menjadi sebuah fakta yang berguna bagi yang membutuhkanya. [4], atau dapat diartikan bahwa sebuah informasi merupakan faktor yang menentukan dalam kemajuan suatu badan usaha maupun individu. Informasi yang berkualitas harus akurat, tepat pada waktunya, jelas dan relevan.[5]

Sistem informasi adalah kombinasi antara prosedur kerja, informasi, orang, dan teknologi informasi yang diorganisasikan untuk mencapai sebuah tujuan dalam organisasi [6], dari definisi di atas dapat diartikan bahwa sistem informasi adalah sebuah kombinasi antara orang teknologi informasi, prosedur yang saling berhubungan untuk mengelola sebuah data yang akan diolah menjadi sebuah informasi yang berguna bagi sebuah organisasi untuk mencapai tujuan, pengolahan sistem informasi yang baik dengan ditunjang dengan teknologi informasi yang baik pula akan mendukung kinerja sebuah organisasi

Kepegawaian merupakan sebuah kegiatan mengelola sumber daya manusia pada sebuah organisasai. Pada dasarnya kepegawaian adalah sebuah kegiatan mengelola kepangkatan, kewajiban, pembinaanpegawai serta hak yang harus didapat oleh pegawai tersebut. Mengelola tenaga kerja manusia haruslah mengelola (mental dan fikiran ) karena kedunya merupakan sebuah modal yang sangat di perlukan dalam menunjang kesuksesan sebuah organisasi [7]

SDN Binakarya 1 merupakan sebuah sekolah dasar negeri yang berada di Jln. Adiwinata merupakan salah satu sekolah yang memiliki fasilitas cukup lengkap serta tenaga pegawai yang memadai, di bagian administari sekolah sendiri memiliki pegawai meliputi pegawai striktural maupun (pegawai administrasi) dan pegawai fungsional (guru) maka dari itu untuk memudahkan mengelola semua kebutuhan administrasi ang dibutuhkan sebuah sistem kepegawaian (SIMPEG).

Operator Sekolah/ Bagian Administrasi di SDN Binakarya 1 memiliki tugas untuk melakukan pencatatan KGB, pengelolaan data pegawai sekolah, pengusulan kenaikan pangkat PNS, pensiunan pegawai. Berdasarkan hasil dari observasi serta wawancara yang di lakukan dengan salah satu pegawai di SDN Binakarya 1, pencatatan administrasi masih manual mengunakan buku bahkan kadang tidak dicatat sama sekali sehingga data-data mengenai kepegawaian kadang hilang atau berserakan,hal ini juga menyebabkan pada saat pengajuan kepangkatan maupun penggajuan kepensiunan yang membutuhkan arsip dari bagian adminstrasi yang tidak tertata dengan rapi menyebabkan pengajuan pensiun menjadi lebih lama karena tidak terorganisasinya penyimpanan arsip tersebut.

Berdasarkan permasalahan yang telah di paparkan di atas maka di lakukan penelitian dengan tema "Perancangan Sistem Informasi Kepegawaian Berbasis Website Di Bagian Administrasi SDN Binakarya 1 Kabupaten Garut" semoga penelitian yang di lakukan di SDN Binakarya 1 ini dapat membantu permasalahan yang ditemui dalam pengolahan data kepegawaian di instansi tersebut.

\section{METODOLOGI PENELITIAN}

\subsection{Objek Penelitian}

Objek Yang dijadikan bahan peneniltian dalam penulisan penelitian ini adalah Bagian administrasi di Sekolah di SDN Binakarya 1 Jln. Adiwinata Desa Binakarya Kecamatan Banyuresmi Kabupaten Garut,

\subsection{Desain Penelitian}

Dalam penelitian ini pengumpulkan data mengunakan metode penelitian deskriptif serta metode penelitian tindakan (action research). Metode penelitiandeskriptif yaitu sebuah metode penelitian dimana seorang peneliti akan melakukan sebuah penelitian dari sebuah gambaran masalah kemudian peneliti akan mengumpulkan data dari data tersebut di ambil gambaran keadaan yang di dasarkan kepada fakta

\subsection{Metode Pendekatan Dan Pengembangan Sistem}

Untuk metode yang digunakan dalam pembuatan sistem informasi kepegawaian ini adalah metode pendekatan object oriented, pertama kali digunakan pada sekitar tahun 19600an di norwegia oleh dua orang peneliti keungulan pengunaan metode pendekatan mengunakan OOP (Object Oriented Programming) adalah dikarenakan memiliki fleksibilitas yang lebih baik, serta lebih mudah dipelajari oleh pemula. 
Metode prototype digunakan sebagai metode untuk pengembangan sistem kepegawaian (SIMPEG). Motode prototype adalah model SDLC yang paling sederhana, model ini menggambarkan kebutuhan maupun spesifikasi yang di inginkan oleh user kepada pengembang system atau lebih jelasnya tentang proses metode prototype dapat dilihat pada gambar di bawah ini.

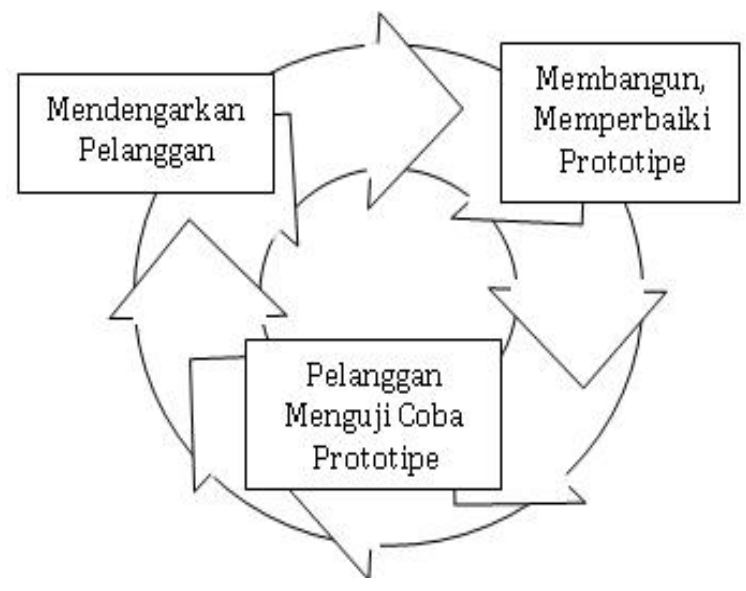

Gambar 1. Model Protype[8]

\section{HASIL DAN PEMBAHASAN}

\subsection{Perancangan Sistem}

Pada bagian ini akan menjelaskan bagaimana perancangan sistem yang merupakan suatu tahapan dari metediologi pembangunan suatu perangkat lunak yang telah melalui proses ataupun tahapan analisis.

\subsubsection{Gambaran Umum Sistem Yang Diusulkan}

Gambaran dari sistem kepegawaian ini adalah sebuah sistem berbasis website yang mana setiap pegawai yang berada di SDN Binakarya 1 dapat melakukan proses kepegawaian dimana saja tanda ada halangan. Serta sistem ini diharapkan dapat membantu pengarsipan doken yang lebih rapi yang membuat proses kepegawaian dapat dilakukan dengan lebih cepat dan efisien tanpa memakan waktu yang lama karena arsip yang tidak terorganisir dan belum terintegrasi

\subsubsection{Perancangan Prosedur Yang Diusulkan}

Karena prosedur yang sudah baku dari dinas pendidikan maka perancang tidak mengajukan prosedur baru dan masih mengunakan prosedur yang telah berjalan hanya saja setiap pekerjaan manual diganti menjadi otomatis seperti sebagai berikut : 


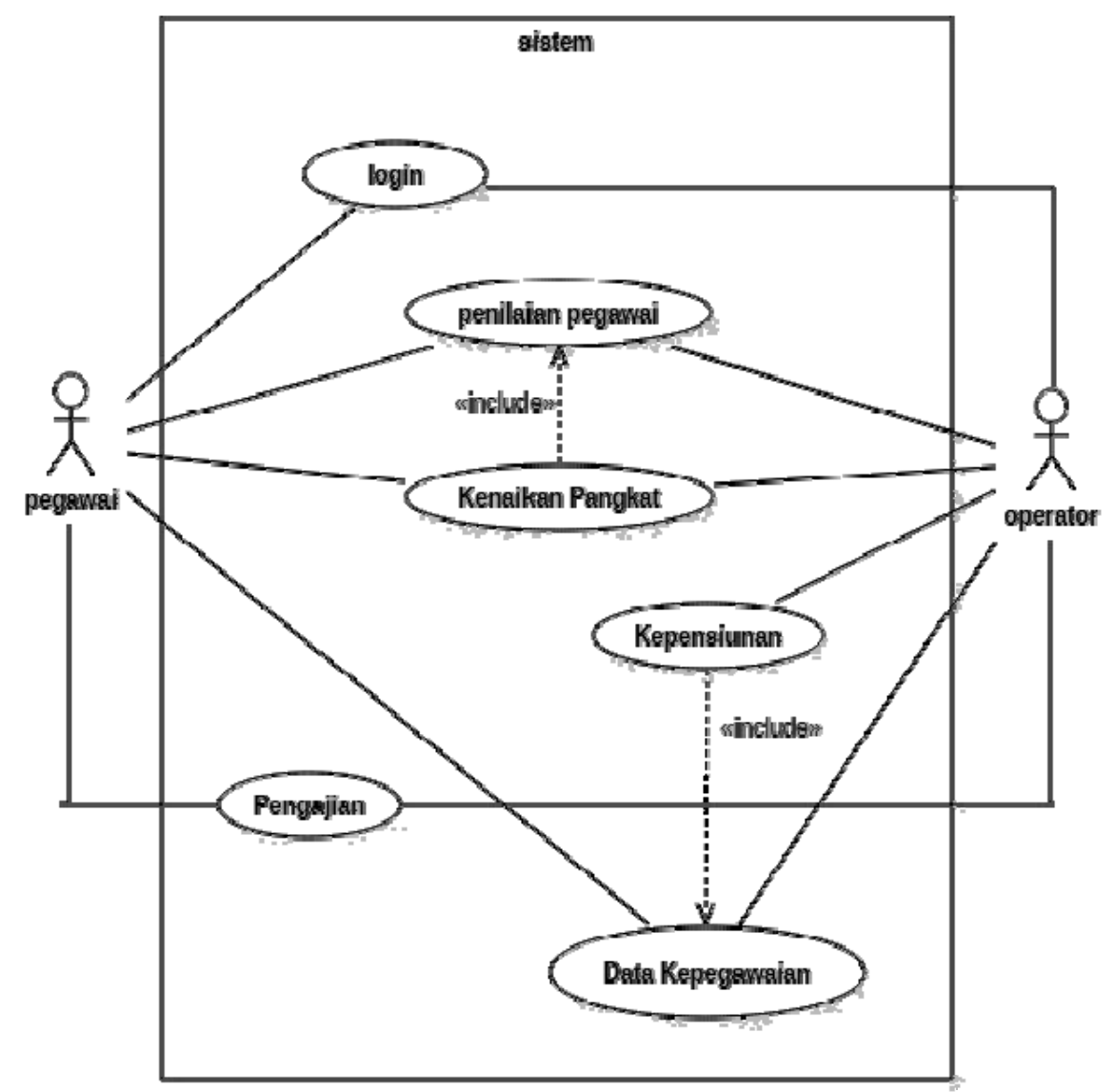

Gambar 2. Diagram Usecase Sistem Informasi Kepegawaian Berbasis Website

Dari gambar diatas dapat di sekenariokan alur dari usecase adalah sebagai berikut sebagai berikut :

a) Pegawai menyerahkan data kepegaiwan berupa SK pengankatan PNS bagi PNS, Riwayat pendididkan terakhir, riwayat hidup, daftar susunan keluarga untuk di inputkan kepada sistem oleh Operator Sekolah

b) Operator Sekolah akan mencatat data kepegawaian yang diserahkan oleh pegawai

c) Gaji yang di terima dari dinas pendidikan kecamatan akan di catat oleh Operator Sekolah pada sistem kemudian di serahkan pada pegawai

d) Untuk penilaian pegawai setelah penilaian dilakukan oleh assesor lembar tersebut akan dibuatkan salinannya untuk di inputkan dan upload pada sistem yang kemudian akan diserahkan pada pegawai tersebut.

e) Untuk pengajuan kenaikan pangkat pegawai mengecek apakah dia sudah dapat mengajukan kenaikan pangakat dari sistem jika sudah memenuhi persyaratan sitem akan mengalihkan pegawai pada halaman kenaiakan pangkat.

f) Untuk pengajuan pensiun pegawai akan mengunduh persyaratan dari sistem.

\subsubsection{Pengujian Sofware}

Pengujian aplikasi digunakan untuk menguji fungsional sebuah software bagaimana softwarre itu melakukan input proses dan output apakah sudah sesuai dengan rancangan awal software, pengujian aplikasi sendiri mengunakan metode blackbox dengan menguji fungsionalitasnya. 
Tabel 1. Pengujian sistem informasi kepegawaian berbasis website

\begin{tabular}{lll}
\hline No & Item pengujian & Hasil uji \\
1. & Form login & Sesuai \\
2. & Form tambah data pegawai & Sesuai \\
3. & Form tambah data riwayat pendidikan & Sesuai \\
4. & Form tambah data riwayat kursus & Sesuai \\
5. & Form tambah data riwayat golongan & Sesuai \\
6. & Form tambah data riwayat jabatan & Sesuai \\
7. & Form tambah data riwayat suami istri & Sesuai \\
8. & Form tambah data riwayat anak & Sesuai \\
9. & Form tambah data riwayat orangtua & Sesuai \\
10. & Form tambah data riwayat mertua & Sesuai \\
11. & Form tambah data riwayat saudara & Sesuai \\
12. & Form tambah data riwayat diklat & Sesuai \\
13. & Form tambah data riwayat penghargaan & Sesuai \\
14. & Form tambah data riwayat kunjungan luar negeri & Sesuai \\
15. & Form KGB & Sesuai \\
16. & Tombol ajukan kenaikan pangkat & Sesuai \\
17. & Form DP3 & Sesuai \\
18. & Form PAK & Sesuai \\
19. & Function edit & Sesuai \\
\hline
\end{tabular}

Terlihat dari table di atas bahwa pengujian software yang telah dilakukan pada tahap pengujian aplikasi memiliki hasil uji "Sesuai"yang dapat diartikan bahwa semua proses masukan (input) maupun keluaran (output) dari software sesuai dengan apa yang di inginkan oleh user.

\section{KESIMPULAN} berikut :

Berdasarkan hasil dari perancangan yang telah di buat maka ditarik sebuah kesimpulan sebagai

a) Dengan adanya sebuah database yang menyimpan data pegawai dan membuat sebuah fungsi yang dapat membuat sebuah persyaratan kenaikan pangkat dan pengajuan pensiun pegawai, sehingga dapat menghemat waktu.

b) Dengan adanya sebuah Database yang mengintegrasikan data-data kepegawaian menjadi saling terintegrasi

c) Dengan adanya Database yang terintegrasi maka pembuatan laporan akan lebih mudah.

\section{UCAPAN TERIMA KASIH}

Ucapkan terimakasih terhadap pihak-pihak yang senangtiasa memberikan dukungan sehingga dapat menyelesaikan penulisan penelitian ini yaitu kepada :

1) Dr. Ir. Eddy Soeryanto Soegoto, M.Sc selaku Rektor Universitas Komputer Indonesia

2) Prof.Dr.H.Denny Kurniadie, Ir.,M.Sc selaku Dekan Fakultas Teknik dan Ilmu Komputer Universitas Komputer Indonesia

3) Marliana Budhiningtias W., S.Si.,M.Si selaku Ketua Program Studi Sistem Informasi Universitas Komputer Indonesia sekaligus dosen wali.

4) Pihak dari SDN Binakarya 1 yang telah mengijinkan penelitian.

\section{DAFTAR PUSTAKA}

[1] Martin, E. "Managing Information Technology What Managers Need to Know (3rd ed.)" New Jersey, :Pearson Education International. 1999

[2] William and Sawyer. "Using Information Technologi " Yogyakarta:Andi, 2007

[3] Jogiyanto "Analisis dan Disain Informasi Pendekatan Terstruktur Teori dan Praktek Aplikasi Bisnis.” Yogyakarta , : Andi Offset. 2005.

[4] Kristanto, Andri, "Perancangan Sistem Informasi dan aplikasinya.”. Yogyakarta. : Gava Media , 2008

[5] Ibrahim, Ali. 2011. "Perancangan Sistem Pemesanan Tiket Pesawat Berbasis Web". Jurnal Sistem Informasi (JSI)3. 1, 320-326. 
Jurnal SIMETRIS, Vol 8 No 2 November 2017

ISSN: 2252-4983

[6] Alter, S. "Information System: A Management Perspective." San Francisco: The Benjamin/Cummings Publishing Company, Inc. 1992

[7] Hani Handoko,. "Manajemen Personalia dan Sumberdaya Manusia." Yogyakarta: BPFEYogyakarta. 1989

[8] Shalahuddin, M. Dan Rosa A.S, "Rekayasa Perangkat Lunak Terstruktur danBerorientasi Objek", ed 1, Bandung : Informatika, 2013 